\title{
The Newest Survey on Language Attitude of Sundanese Urban Community in West Java Province, Indonesia Against Sundanese, Indonesian, and Foreign Language: A Study on Multilingual Speaker
}

\author{
Ade Mulyanah*, M. Hum \\ West Java Language Center, National Language Agency, Ministry of Education and Culture of Indonesia, Indonesia
}

Corresponding Author: Ade Mulyanah, E-mail: Ad_ariell@yahoo.com

\section{ARTICLE INFO}

\section{Article history}

Received: September 07, 2017

Accepted: November 23, 2017

Published: January 05, 2018

Volume: 7 Issue: 1

Advance access: December 2017

Conflicts of interest: None

Funding: None

\begin{abstract}
This research intends to describe the newest survey on the language attitude of the Sundanese, West Java, Indonesia Urban Community against Sundanese, Indonesian, and foreign language. The methodology of the reserach is quantitative method. Although most of the people in West Java are Sundanese, most of them are multilingual. Therefore, the writer tries to find the language attitude of Sundanese toward Sundanese, Indonesia, and foreign language. Respondents involved in the research are 324 respondents living in Bogor city, 84 respondents living in Bandung city, and 92 respondents living in Bekasi city. The study seeks to discover how Sundanese people shift their language in their communication. Based on Keller's theory (1968), language shift caused more by the emergence of the industry. The three cities are industrial area where people are possibly to choose certain language in communication. Furthermore, Cooper (1978) showed that the role of language became the lingua franca (in this case, including Indonesian) often urged the local language. The result of the research indicates that (1) the attitude of the Sundanese urban community in West Java to the Sundanese language is good category, because the average only reaches $64.11 \%$. The language attitude of people in Bogor is the lowest among the three cities. (2) The language attitude of the Sundanese urban community in West Java to the Indonesian language is in fair category, because the average is only $56.19 \%$. The lowest language attitude of urban community in West Java toward Indonesian language is Bekasi.(3) The attitude of the Sundanese urban community in West Java to foreign languages is in good category because the average reaches $69.85 \%$. The highest language attitude toward foreign language is Bogor. Since this is the newest survey on language attitude on urban community in West Java, it will be very significant findings for those who are interested in multingual conditions in West Java, Indonesia.
\end{abstract}

Key words: Language Attitude, Sundanese, Sciolinguistics, Multilingual

\section{INTRODUCTION}

Sundanese people are one of the ethnic group in Indonesia which has Sundanese language as their mother tongue. However, they are multilingual. Multilingualism refers more to the description of a speaker who speaks more than two languages, it can be three languages, or four, even five languages at once. Its use is almost the same as bilingualism, which knows when and where a language will be used. For example, the Javanese, in addition to being able to speak Javanese (as their mother tongue), also able to speak Indonesian as B2, and English as B3, some even Japanese, Dutch, and so on. As multilingual speakers, it prone to misconduct by Sundanese speakers when using Indonesian language.

Sundanese language spoken by the people of Indonesia, especially in the island of West Java. This language is not only spoken in the western part of Java, but is also spoken on various islands in Indonesia by Sundanese migrants to the place. Sundanese is also spoken abroad especially in ar- eas where migration of Sundanese people. According to the 2000 census data Sundanese language spoken by 34 million inhabitants. Sundanese has several dialects, among them the western dialect (southern Banten), the northern dialect (Bogor, and its surroundings), the southern dialect/the Priangan dialect (Bandung and its surroundings, the middle east dialect (Majalengka and its surroundings), the northeastern dialect.

The study on Sundanese language attititude toward in West Java related to Sundanese urban community in West Java has been conducted (Mulyanah, 2017). The study only focuses on Sundanese language attitude related to their educational background. The study reveals that there is no significant corelation between respondents' educational background and their language attitude.

However, the study on language attititude in multicultural speakers in urban community in West Java is still limited. The research on Sundanese language attitude is signinificant 
to carry out since they are multicultural speakers. It can give description on Sundanese language attitude toward their languages used by them. Hence, the research will give contribution on those who need to understand about Sundanese attitude toward their language.

\section{Research Questions}

The research is based on the following questions.

(1) What is the attitude of the urban Sundanese towards Sundanese language?

(2) What is the attitude of the urban Sundanese towards the Indonesian language?

(3) What is the attitude of the urban Sundanese towards foreign languages?

\section{Aims of the Research}

Regarding to the research questions, the aims of the research are the followings.

(1) To describe the language attitude of urban Sundanese in West Java toward Sundanese language

(2) To describe the language attitude of urban Sundanese tward Indonesian language

(3) To describe the language attitude of urban Sundanese tward foregn language.

\section{THEORETICAL FRAMEWORK}

The research is based on the following theories. The theories support the research dealing with sociolinguistics and language attitude concepts.

\section{Sociolinguistic Theory}

The sociolinguistic theory is concerned with the theory of language attitudes because sociolinguistics views language as a social institution, both individuals and societal groups that engage in social interaction. According to Fishman (1972) sociolinguistics is a study of the characteristics of language variation, the functions of language variation, and language users because the three elements are always interacting, changing and mutually altering each other in a society.

Meanwhile, according to Hudson (1996: 1--2), sociolinguistics covers a vast field of study, not only of the formal form of language and its variation, but also of language use in society. The use of language includes linguistic and non-biological factors. On that basis, sociolinguistic view of a language is composed of a variety that is formed from existing social groups. Thus, it can be understood that in each community group there are social and cultural values that are specific to the use of their language that is different from other community groups.Sociolinguistics as a science that is considered new and demands its presence parallel to other sciences. Sociolinguistics demands its participation in providing information for the adoption of language policies, including language policy. This is due to sociolinguistic studies connecting language with social and cultural phenomena.
Fasold (1990) suggests that multilingualism serves as an interactional resource for the multilingual speaker. This means that one particular language may normally be used at home or with close friends, whereas another language may be used for commerce and trade, and even a third one for dealing with government agencies.

\section{Language Attitude}

Language is a mental attitude or feelings towards the position of its own language or language of others (Kridalaksana, 2001:197). In the Indonesian langauge, the word language attitudes can refer to the body shape, the upright standing position, behavior or gestures, and actions or action taken based on the view (establishment, beliefs, or opinions) as a reaction to the existence of a thing or event.

This research is based on linguistic knowledge and attitude of Sundanese toward Sundanese, Indonesia, and foreign langauge. Research data in the form of respondents' answers to questions and statements of questions posed through a questionnaire/questionnaire. In other words, the object of this study is the answers and responses that contain knowledge and attitude multingual respondents using language, both Indonesian and foreign languages.

Language attitude is formed from the word attitude and language. Attitude is 'deeds and so on based on the establishment or belief'. Furthermore, language is given the meaning of 'an arbitrary system of symbolic sounds used by members of a society to cooperate, interact, and identify.' (KBBI, 2003). Furthermore, Garvin and Mathiot (1968) establishes that language attitudes contain at least three basic features, namely:

(1) Language loyalty a language that encourages the community to maintain its language and if necessary to prevent the influence of other languages.

(2) Language pride which encourages people to develop the language and use it as a symbol of community identity and unity.

(3) Language awareness to language which encourages people to use language carefully and courteously, is a huge factor influencing on the act, which is the using language use.

The three characteristics are the positive attitudes toward language. If it is weakened or has disappeared from a person or from a community, it means there has been a negative attitude towards the language.

Ihemere's (2006) research seeked to discover language attitudes and change in Nigeria by investigating the Ikwerre attitudes to their languages, Ikwerre, and Nigerian Pidgin English. The study formulated that Ikwerre is a dialect in Nigeria while Nigerian Pidgin English is their standard language.

Another study is also conducted by Gal (1987). He stated that the analysis of language choice in bilingual and multilingual is crucial matter in sociolinguistic research. Early investigation by linguists and sociologists at depicting language use in general quantitative terms have failed to account for the evident heterogeneity across communities, individuals and occasions. He also suggested that theoreti- 
cally refined tools are needed to explain why language $\mathrm{X}$ is used in situation $\mathrm{x}$, and why language $\mathrm{Y}$ is used in situation y. However, it is widely assumed that language use is unsystematic, sociolinguistics has held as axiomatic that a speaker's choice in determining the langauge between varieties is also structured. Based on Gal (1987: 287) it is systematically linked to social relationships, events or situations. Therefore, one of the fundamental issues in socially oriented linguistic disciplines is why a given linguistic variety is chosen to be used in a particular array of situatios, while another variety is preferred in other circumstances.

Also, Gumperz (1964) uses the term 'linguistic repertoire' to describe the range of styles which an individual needs to fulfill all his or her communicative needs in the most appropriate way. The speaker is able to choose the appropriate variety for any particular purpose is part of his or her communication; the choice is not random. However, it has been shown to be determined by aspects of the social organization of the community and the social situation where the discourse occurs. In this case the bilingual or the multilingual is not strikingly different from the monolingual; therefore, it can be said that it is simply that a speaker has to choose not only between different varieties of the same language, but also between two or more different languages.

Holmes (2008) also believes that people classify different languages or varieties as elegant, expressive, vulgar, musical, polite, impolite, pleasing or unpleasing. This categorization has influenced the users' attitudes towards the language because it reflects they are and represents the social groupings they belong to. Thus, people develop either a positive or negative attitude to other languages based on how the community categorized them. A language becomes appealing to the speakers who have positive attitude towards it and prefer it in most of their interactions. Nevertheless, if speakers have negative attitudes towards a language, they develop resistance in using it.

\section{METHODOLOGY}

\section{Method}

The method used in this study is a survey, a quantitative research. The primary data was taken by using questionnaire. The study took a sample of the population and Data Collection and Processing Techniques. The data used is the data obtained through the questionnaire, based on the Likert Scale to know the attitude of the urban community language. The data obtained is quantitative data, i.e., data in the form of numbers of measurement results in the form of questions related to knowledge of legislation and statements about attitude.

\section{Population and Sample}

The sample used in this study are from a population of 500 people representing the Sundanese people in urban areas in West Java in three big cities in West Java, namely, Bandung, Bogor, and Bekasi. It consists of 324 respondents living in the city of Bogor, 84 respondents living in the city of Bandung, and 92 respondents living in the city of Bekasi.

\section{Data Collection Technique}

The study was conducted using a Likert-scale questionnaire consisting of 23 questions related to Sundanese, 7 questions related to Indonesian, and 5 questions related to foreign languages. Each statement has 5 response alternatives, namely: Strongly Agree (SS), Agree (S), Hesitant (R), Disagree (TS), and Strongly Disagree (STS).

After the data collected, the data is processed with the following steps. (1) The first stage creates a tabulation of questionnaire scores of knowledge and attitude of the developer's language developers and (2) the second stage makes the overall score of the test results.

Because the data of quantification result is ordinal scale data, then before data analysis is done transformation of data from ordinal scale data into interval scale by using Method of Succesive Interval (MSI) with STAT97 software that add in to MS Excel.

After all data is transformed into interval scale, then calculated the total score of attitude of Sundanese urban society toward Sundanese, Indonesian language, and foreign language.

\section{FINDINGS AND DISCUSSION}

Here is the section formulating research findings. The research is answering research question stated in the previous section. The analysis is based on the following criteria. The criteria will be shown on in Tables 1 and 2 .

The findings and the discussion will refer to the following research question.

\section{The Attitude of the Urban Sundanese towards Sundanese Language}

The result of data processing language attitude of Sundanese of urban community in West Java toward Sundanese language is presented in Table 3 and Diagram 1.

From Table 3 it can be seen that in general, the attitude of the Sundanese language in urban areas in West Java to Sundanese average only reaches $64.11 \%$. Therefore the category is good. The language attitude of the Sundanese language of the city of Bogor, West Java Province is only $62.66 \%$ in average. The category is good. The language attitude of the Sundanese in Bandung is $67.91 \%$ so that is in good category. The language attitude of the Sundanese community in Bandung is only $65.77 \%$ so that the category is good.

It can be concluded that the attitude of the Sundanese urban community in West Java to the Sundanese language is in good category as the average only reaches $64.11 \%$.

If viewed by category, it turns out the attitude of the Sundanese urban community in the city of Bogor, Bandung, and Bekasi is equal that is in good category. However, when viewed from the average value as shown in Diagram 1 there is an indication that the average is different. To be more convincing, the average difference of langauge attitude urban community 
Table 1. Average scoring interpretation guidelines (\%) Language attitude

\begin{tabular}{lll}
\hline No. & $\begin{array}{l}\text { Average knowledge } \\
\text { score }(\%)\end{array}$ & $\begin{array}{l}\text { Language } \\
\text { attitude category }\end{array}$ \\
\hline 1 & Rata-rata $\geq 84,00$ & Excellent \\
2 & $68,00 \leq$ Rata-rata $<84,00$ & Good \\
3 & $52,00 \leq$ Rata-rata $<68,00$ & Fair \\
4 & $36,00 \leq$ Rata-rata $<52,00$ & Poor \\
5 & Rata-rata $<36,00$ & Very poor \\
\hline
\end{tabular}

Table 2. Guidelines for interpretation percentage of answers to each questionnaire statement

\begin{tabular}{ll}
\hline Percentage of answers $(\mathbf{P})$ & Interpretation \\
\hline $\mathrm{P}=0,00$ & No interpretation \\
$0,00<\mathrm{P} \leq 5,00$ & Almost no interpretation \\
$5,00<\mathrm{P} \leq 25,00$ & A small part \\
$25,00<\mathrm{P}<50,00$ & Almost a half \\
$\mathrm{P}=50,00 \%$ & A half \\
$50,00<\mathrm{P} \leq 75,00$ & More than a half \\
$75,00<\mathrm{P} \leq 95,00$ & Most of \\
$95,00<\mathrm{P}<100,00$ & Nearly all \\
$\mathrm{P}=100 \%$ & All \\
\hline
\end{tabular}

Table 3. Respondents' Language attitude toward Sundanese

\begin{tabular}{lcccc}
\hline & Bogor & Bandung & Bekasi & Total \\
\hline $\mathrm{N}$ & 324 & 84 & 92 & 500 \\
Mean & 62.6608 & 67.9121 & 65.7654 & 64.1143 \\
Standard deviation & 10.79577 & 9.00728 & 8.87015 & 10.37241 \\
Standard error & 0.59977 & 0.98278 & 0.92478 & 0.46387 \\
95\% confidence & & & & \\
interval for mean & & & & \\
$\quad$ Lower bound & 61.4808 & 65.9574 & 63.9285 & 63.2029 \\
$\quad$ Upper bound & 63.8407 & 69.8668 & 67.6024 & 65.0256 \\
Minimum & 28.64 & 47.33 & 46.72 & 28.64 \\
Maximum & 93.16 & 96.82 & 93.20 & 96.82 \\
\hline
\end{tabular}

in Bogor, Bandung and Bekasi city is done by using one-way ANOVA test. The test results against the classical requirements of the one-channel ANOVA test, i.e. each data of language attitude of normal distribution and homogeneous variation has been fulfilled at the level of significance $\alpha=0.05$. The analysis will be shown in Anova test results 1 path.

\begin{tabular}{lccccc}
\hline \multicolumn{7}{l}{ Attitude toward Indonesian } & & & \\
\hline & $\begin{array}{c}\text { Sum of } \\
\text { squares }\end{array}$ & df & $\begin{array}{c}\text { Mean } \\
\text { square }\end{array}$ & F & Sig. \\
\hline $\begin{array}{l}\text { Between } \\
\text { groups }\end{array}$ & 2146.927 & 2 & 1073.464 & 10.352 & 0.000 \\
$\begin{array}{l}\text { Within } \\
\text { groups }\end{array}$ & 51538.978 & 497 & 103.700 & & \\
Total & 53685.905 & 499 & & & \\
\hline
\end{tabular}

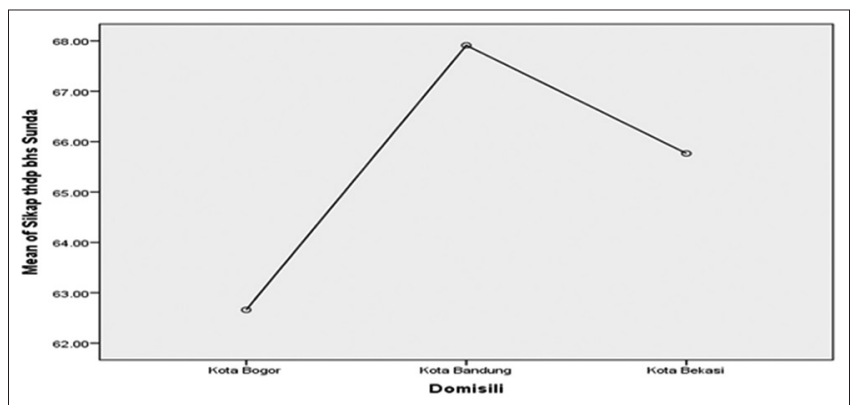

Diagram 1

There are significant differences in attitudes towards Sundanese language between communities living in the city of Bogor, Bandung, and Bekasi. Furthermore, to know which community having different attitude can use done Posthoc test: the difference of attitude processing by using Tukey HSD test. Tukey HSD test results are presented in the following table.

From table Multiple Comparison known thatSig value for differences in attitude toward Sundanese language between people who live in the city of Bogor and the city of Bandung is 0.000. Because the value of Sig. $=0.000<\alpha=$ 0,05 then Ho: there is no difference of attitude toward Sundanese language between society living in Bogor city and Bandung city so it is rejected at significance level $\alpha=0,05$. Furthermore, from Mean Difference it is known that the value is -5.25 . This shows that the attitude of the people of Bandung to Sundanese language is significantly higher than the people of Bogor city. Average difference of $5.25 \%$ means at significance level $\alpha=0.05$.

Sig value for differences in attitude toward Sundanese language between people who live in the city of Bogor and the city of Bekasi is equal to 0.027. Because the value of Sig. $=0,027<\alpha=0,05$ then Ho: there is no difference of attitude toward Sundanese language between society domiciled in Bogor city and Bekasi city is rejected at significance level $\alpha$ $=0,05$. Furthermore, from Mean Difference it is known that the value is -3.10 . This shows that the attitude of the people of Bekasi to Sundanese is significantly higher than the people of Bogor city. The average difference of $3.10 \%$ means at the significance level $\alpha=0.05$.

Sig value. For the difference of attitude toward Sundanese language between people who live in Bandung and Bekasi is 0,343. Because the value of Sig. $=0,343>\alpha=0,05$ then Ho: there is no difference of attitude toward Sundanese language between society living in Bogor city and Bekasi city so it is accepted at significance level $\alpha=0,05$. Furthermore, from Mean Difference it is known that the value is 2.15. This shows that the attitude of the people of Bandung to Sundanese language is higher than the people of Bekasi city but the average difference of $2.15 \%$ does not mean at the level of significance $\alpha=0.05$.

Based on the above statistics description, we can find the followings findings.

1. The language attitude of the Sundanese urban community in West Java to Sundanese language is in good category.

2. There is a difference from language attitude among urban Sundanese living in Bogor, Bandung, and Bekasi. 
Table 4. Multiple comparisons

\begin{tabular}{llccccc}
\hline \multirow{2}{*}{$\begin{array}{l}\text { Dependent variable: Language attitude toward Sundanese } \\
\text { (I) City }\end{array}$} & $\begin{array}{l}\text { (J) urban community } \\
\text { living in }\end{array}$ & $\begin{array}{c}\text { Mean } \\
\text { difference }(\mathbf{I}-\mathbf{J})\end{array}$ & Standard error & Sig. & \multicolumn{2}{c}{$\mathbf{9 5 \% \text { confidence interval }}$} \\
\hline \multirow{2}{*}{ Bogor } & Bandung & $-5.25137^{*}$ & 1.24683 & 0.000 & -8.1824 & -2.3204 \\
& Bekasi & $-3.10466^{*}$ & 1.20301 & 0.027 & -5.9326 & -0.2767 \\
\multirow{3}{*}{ Bandung } & Bogor & $5.25137^{*}$ & 1.24683 & 0.000 & 2.3204 & 8.1824 \\
& Bekasi & 2.14671 & 1.53678 & 0.343 & -1.4659 & 5.7593 \\
Bekasi & Bogor & $3.10466^{*}$ & 1.20301 & 0.027 & 0.2767 & 5.9326 \\
& Bandung & -2.14671 & 1.53678 & 0.343 & -5.7593 & 1.4659 \\
\hline
\end{tabular}

*The mean difference is significant at the 0.05 level

3. The language attitude of Bandung community attitude towards Sundanese language is significan in Bogortly higher than the people of Bogor city.

4. The language atttitude of Bandung community attitude towards Sundanese language is higher than Bekasi city community but not significant.

5. The language attitude of Bekasi community to Sundanese is significantly higher than the people of Bogor city.

6. The language attitude of people in Bogor is the lowest among the three cities.

\section{The Attitude of the Urban Sundanese towards the Indonesian Language}

The result of data processing attitude of Sundanese urban community in West Java to Sundanese language is presented in Table 5 and Diagram 2 below.

In general, the language attitude of the Sundanese urban community in West Java to the Indonesian language only reaches $56.19 \%$ so that it is in fair category. The language attitude of the Sundanese language of urban community in Bogor West toward Indonesian language a only reaches $55.53 \%$ so that it is in fair category. The language attitude of the Sundanese community in Bandung toward the Indonesian language average only reaches $58.85 \%$ so that it includes a good category. The attitude attitude of the Sundanese community in Bekasi to the Indonesian language only reaches $56.10 \%$ so that it includes in fair category. From the stantistic we can observe that the lowest language attitude of urban community in West Java toward Indonesian language is Bekasi.

From the above analysis, it can be summarized that the attitude of the Sundanese urban community in West Java to the Indonesian language is sufficient, because the average is only $56.19 \%$.

If viewed by category, it turns out the language attitude of the Sundanese urban community in the city of Bogor, Bandung, and the city of Bekasi against the Indonesian language is equal, which is included in fair category. However, when viewed from the average value as shown in Diagram 3 there is an indication that the average is differ-
Table 5. Language attitude toward Indonesian language

\begin{tabular}{lcccc}
\hline & $\begin{array}{c}\text { Bogor } \\
\text { city }\end{array}$ & $\begin{array}{c}\text { Bandung } \\
\text { city }\end{array}$ & $\begin{array}{c}\text { Bekasi } \\
\text { city }\end{array}$ & Total \\
\hline $\mathrm{N}$ & 324 & 84 & 92 & 500 \\
Mean & 55.5265 & 58.8546 & 56.1046 & 56.1920 \\
Standard deviation & 9.82654 & 8.98681 & 7.80495 & 9.40895 \\
Standard error & 0.54592 & 0.98054 & 0.81372 & 0.42078 \\
95\% confidence & & & & \\
interval for mean & & & & \\
$\quad$ Lower bound & 54.4525 & 56.9044 & 54.4882 & 55.3653 \\
Upper bound & 56.6005 & 60.8049 & 57.7209 & 57.0187 \\
Minimum & 23.58 & 37.81 & 37.17 & 23.58 \\
Maximum & 85.61 & 87.95 & 72.67 & 87.95 \\
\hline
\end{tabular}

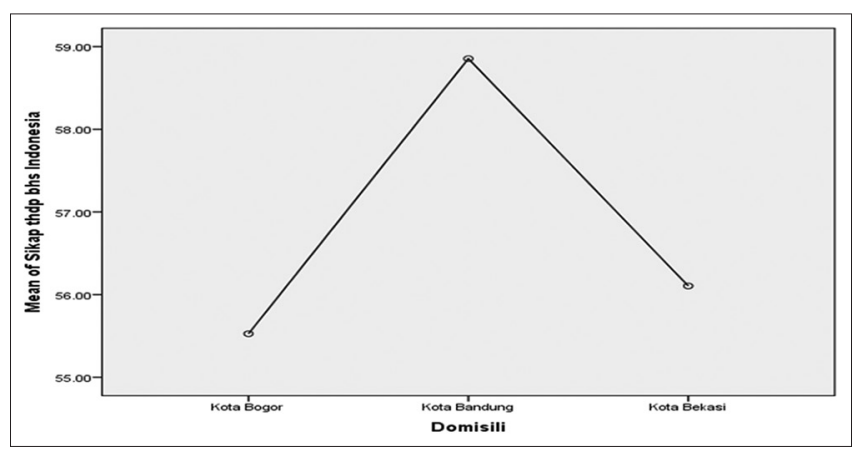

Diagram 2

ent. To be more convincing, we should do test difference of average attitude of society of city of Bogor, Bandung city, and city of Bekasi by using Kruskal Wallis test. This test was chosen because the data of attitude of urban Sundanese society in Bogor city is not normal distribution, while for Bandung and Bekasi city normal distribution at significance level $\alpha=0,05$.

Result of Kruskal Wallis.

From Statistical Test table known Sig value. $=0.023$. Because the value of Sig. $=0,023<\alpha=0,05$ then Ho: there is no difference of attitude toward Indonesian language between society domiciled in Bogor city, Bandung city and Bekasi city rejected at significance level $\alpha=0,05$. 


\begin{tabular}{lcccc}
\hline Ranks & Domicily & N & Mean rank & $\begin{array}{c}\text { Sum of } \\
\text { ranks }\end{array}$ \\
\hline $\begin{array}{l}\text { Language } \\
\text { attitude } \\
\text { toward }\end{array}$ & Bogor city & 324 & 208.24 & 67470.00 \\
$\begin{array}{l}\text { Indonesian } \\
\end{array}$ & Bekasi city & 92 & 209.41 & 19266.00 \\
& Total & 416 & & \\
\hline
\end{tabular}

Hence, there are significant differences in attitudes toward Indonesian language between the communities domiciled in Bogor city, Bandung city and Bekasi city.

Furthermore, to find out which community is different attitude, we can do Posthoc test the difference of attitude processing by using Mann Whitney test to test attitude difference to the Indonesian language between people who live in the city of Bogor, Bandung city and between communities domiciled in the city of Bogor and Bekasi city. While the test differences in attitudes toward the Indonesian language between communities live in the city of Bogor were conducted using t-test for two independent samples.

The results of data processing are presented in the following table.

From Statistical Test Table 6 is known Sig value. For differences in attitudes toward the Indonesian language between the people who live in the city of Bogor and the city of Bekasi is equal to 0.934. Because the value of Sig. $=0,934>$ $\alpha=0,05$ then Ho: there is no difference of attitude toward Indonesian language between society residing in Bogor city and Bekasi city accepted at significance level $\alpha=0,05$

Furthermore from the Ranks table is known that the difference in Mean Rank for attitudes toward the Indonesian language community of Bekasi city and Bogor city community is only 1.17 and it is not significant.

\begin{tabular}{lcc}
\hline Independent samples test & \multicolumn{2}{c}{$\begin{array}{c}\text { Language attitude toward } \\
\text { Indonesia language }\end{array}$} \\
\cline { 2 - 3 } & $\begin{array}{c}\text { Equal } \\
\text { variances } \\
\text { assumed }\end{array}$ & $\begin{array}{c}\text { Equal } \\
\text { variances not } \\
\text { assumed }\end{array}$ \\
\hline Levene's test for equality of & & \\
variances & & \\
F & 1.735 & \\
Sig. & 0.190 & \\
t-test for equality of means & & 2.158 \\
t & 2.172 & 165.216 \\
df & 174 & 0.032 \\
Sig. (2-tailed) & 0.031 & 2.75008 \\
Mean difference & 2.75008 & 1.27421 \\
Standard error difference & 1.26607 & \\
95\% confidence interval of & & 0.23425 \\
the difference & & 5.26591 \\
Lower & 0.25124 & \\
Upper & 5.24892 & \\
\hline
\end{tabular}

Table 6. Test statistics ${ }^{\mathrm{a}}$

\begin{tabular}{lc}
\hline & $\begin{array}{c}\text { Language attitude toward } \\
\text { Indonesian language }\end{array}$ \\
\hline Mann-Whitney U & 11016.000 \\
Wilcoxon W & 63666.000 \\
Z & -2.691 \\
Asymp. Sig. (2-tailed) & 0.007 \\
\hline a. Grouping variable: domicily &
\end{tabular}

From the Independent Samples Test table the Sig value is known. For differences in attitude towards the Indonesian language between people who live in the city of Bandung and the city of Bekasi is of 0.031 . Because the value of Sig. $=0,031<\alpha=0,05$ then Ho: there is no difference of attitude toward Indonesian language between society living in Bandung and Bekasi city so that it rejected at significance level $\alpha=0,05$. This means that the attitude of the people of Bandung to the Indonesian language is different (higher) significantly than the people of Bekasi.

Based on the fidings above we can summarize that The language attitude of the Sundanese urban community in West Java to the Indonesian language is fair.There are differences in attitude toward the Indonesian language between people who live in the city of Bogor, Bandung, and Bekasi. The language attitude of urban community in Bandung toward Indonesian language is significantly higher than Bogor city people. Bandung community attitude toward Indonesian language is higher than Bekasi city community but not significant. The language attitude of Bekasi community to Indonesian language does not differ significantly with Bogor city community.

\section{The Attitude of the Urban Sundanese towards Foreign Languages}

The result of data processing attitude of Sundanese urban community in West Java to Sundanese language is presented in Table 7 and Diagram 3 below.

From Table 1 it can be seen that in general, the attitude of the Sundanese urban community in West Java to foreign languages has reached $69.85 \%$ of average so that it includes a good category. The language attitude of the Sundanese language of the city of Bogor, West Java province to the average foreign language has reached $69.95 \%$ so that it includes the good category. The language attitude of Sundanese language in Bandung city of West Java Province against foreign languages has reaches $68.34 \%$ so that it includes a good category. The language attitude of Sundanese language in Bandung city of West Java Province against the foreign language reaches $70.89 \%$ so that it is in a good category.

The language attitude of the Sundanese urban community in West Java to foreign languages is in a good category, because the average has reached $69.85 \%$.

If viewed by category, it turns out the language attitude of the Sundanese urban community in the city of Bogor, Bandung, and t Bekasi against the Indonesian language is equal so it includes in a good category. However, when viewed from 
Table 7. Language attitude toward foreign languages

\begin{tabular}{lcccc}
\hline & $\begin{array}{c}\text { Bogor } \\
\text { city }\end{array}$ & $\begin{array}{c}\text { Bandung } \\
\text { city }\end{array}$ & $\begin{array}{c}\text { Bekasi } \\
\text { city }\end{array}$ & Total \\
\hline $\mathrm{N}$ & 324 & 84 & 92 & 500 \\
Mean & 69.9477 & 68.3446 & 70.8963 & 69.8529 \\
Standard deviation & 12.65335 & 13.30329 & 11.83160 & 12.61712 \\
Standard error & 0.70296 & 1.45151 & 1.23353 & 0.56425 \\
95\% confidence & & & & \\
interval for mean & & & & \\
$\quad$ Lower bound & 68.5647 & 65.4577 & 68.4460 & 68.7443 \\
Upper bound & 71.3307 & 71.2316 & 73.3466 & 70.9615 \\
Minimum & 35.09 & 38.09 & 37.25 & 35.09 \\
Maximum & 100.00 & 100.00 & 100.00 & 100.00 \\
& 69.9477 & 68.3446 & 70.8963 & 69.8529 \\
\hline
\end{tabular}

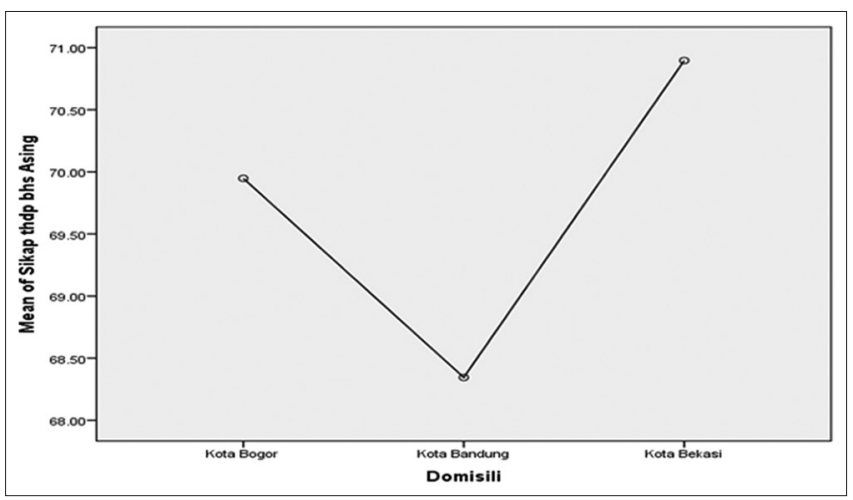

Diagram 3

the average value as shown in Diagram 3 there is an indication that the average is different. To be more convincing, test difference of average langauge attitude of society of city of Bogor, Bandung city, and city of Bekasi can be done by using Kruskal Wallis test. This test was chosen because the data of attitude of urban Sundanese society toward foreign language in Bogor city is not abnormal distribution, while for Bandung and Bekasi city normal distribution is at significance level $\alpha=0,05$.

Here is Result of Kruskal Wallis.

Test statistics $^{\mathrm{a}, \mathrm{b}}$

\begin{tabular}{lc}
\hline & $\begin{array}{c}\text { Language attitude toward foreign } \\
\text { languages }\end{array}$ \\
\hline Chi-square & 2.493 \\
df & 2 \\
Asymp. sig. & 0.288 \\
\hline
\end{tabular}

a. Kruskal Wallis test, b. Grouping variable:

From Statistical Test table it is known Sig value. $=0.228$. Because the value of Sig. $=0,288><\alpha=0,05$ then Ho: there is no difference of attitude toward foreign language between people domiciled in Bogor city, Bandung city and Bekasi city accepted at significance level $\alpha=0,05$.

Therefore, it can be said that there is no significant difference in attitude toward foreign languages between people living in Bogor city, Bandung city and Bekasi.

\section{Comparison of language Attitude toward Sundanese Language And Foreign Languages}

From the Table 8 it can be concluded that:

1. In general, the langauge attitude of the urban community to Sundanese, Indonesian, and foreign languages is in a good category.

2. In general the attitude of the urban community to Sundanese language is in a fair category.

3 . In general the attitude of urban community to Indonesian language is in a fair category.

4. In general, the attitude of the urban community to foreign languages is in a good category.

From Diagram 4 it is seen that the language attitude of urban society tends to show foreign languages in the first rank, the Sundanese language in the second rank, and the Indonesian language is the third/lowest rank. This is a phenomenon that we must closely observe and it is important to conduct further research on what factors cause this phenomenon to occur.

The highest attitude towards Sundanese is owned by Sundanese people who live in Bandung, Bekasi city in the second rank, and the lowest/the third rank in Bogor city.The highest attitude towards the Indonesian language is owned by the Sundanese people who live in the city of Bandung, then the public city of Bekasi, and the lowest city of Bogor. The highest attitude towards foreign languages is owned by Sundanese people who live in Bekasi city, in Bogor city, and the lowest in Bandung city.

Based on this research there are indications that:

1. The language attitude of the Sundanese community in urban towards foreign languages is relatively higher than that of Sundanese or Indonesian.

2. The language attitude of the Sundanese community in urban toward the Indonesian language is in a fair category but the average is under $60 \%$ so it is worrying that need further research.

3. The language attitude of the Sundanese community in urban towards Sundanese is not too worrying compared to the attitude towards the Indonesian language but it must be considered and improved.

\section{CONCLUSIONS AND SUGGESTIONS}

Based on the the data analysis, it can be formulated some conclusions and suggestions.

\section{Conclusion}

From the data analysis in the previous section, here are the following conclusions.

(1) The attitude of the Sundanese urban community in West Java to the Sundanese language is in a good category, because the average only reaches $64.11 \%$. The language attitude of people in Bogor is the lowest among the three cities.

(2) The language attitude of the Sundanese urban community in West Java to the Indonesian language is in a fair category because the average is only $56.19 \%$. The lowest language attitude of urban community in West Java toward Indonesian language is Bekasi. 
Table 8. Dependent variable: Attitude toward Language

\begin{tabular}{|c|c|c|c|c|c|}
\hline Language & City & Mean & Standard deviation & $\mathbf{N}$ & Category \\
\hline \multirow[t]{4}{*}{ Sundanese language } & kota Bogor & 62.66 & 10.80 & 324 & Fair \\
\hline & kota Bandung & 67.91 & 9.01 & 84 & Fair \\
\hline & kota Bekasi & 65.77 & 8.87 & 92 & Fair \\
\hline & Total & 64.11 & 10.37 & 500 & Fair \\
\hline \multirow[t]{4}{*}{ Indonesian language } & kota Bogor & 55.53 & 9.83 & 324 & Fair \\
\hline & kota Bandung & 58.85 & 8.99 & 84 & Fair \\
\hline & kota Bekasi & 56.10 & 7.80 & 92 & Fair \\
\hline & Total & 56.19 & 9.41 & 500 & Fair \\
\hline \multirow[t]{4}{*}{ Foreign language } & kota Bogor & 69.95 & 12.65 & 324 & Good \\
\hline & kota Bandung & 68.34 & 13.30 & 84 & Good \\
\hline & kota Bekasi & 70.90 & 11.83 & 92 & Good \\
\hline & Total & 69.85 & 12.62 & 500 & Good \\
\hline \multirow[t]{4}{*}{ Total } & kota Bogor & 62.71 & 12.60 & 972 & Fair \\
\hline & kota Bandung & 65.04 & 11.46 & 252 & Fair \\
\hline & kota Bekasi & 64.26 & 11.41 & 276 & Fair \\
\hline & Total & 63.39 & 12.23 & 1500 & Fair \\
\hline
\end{tabular}

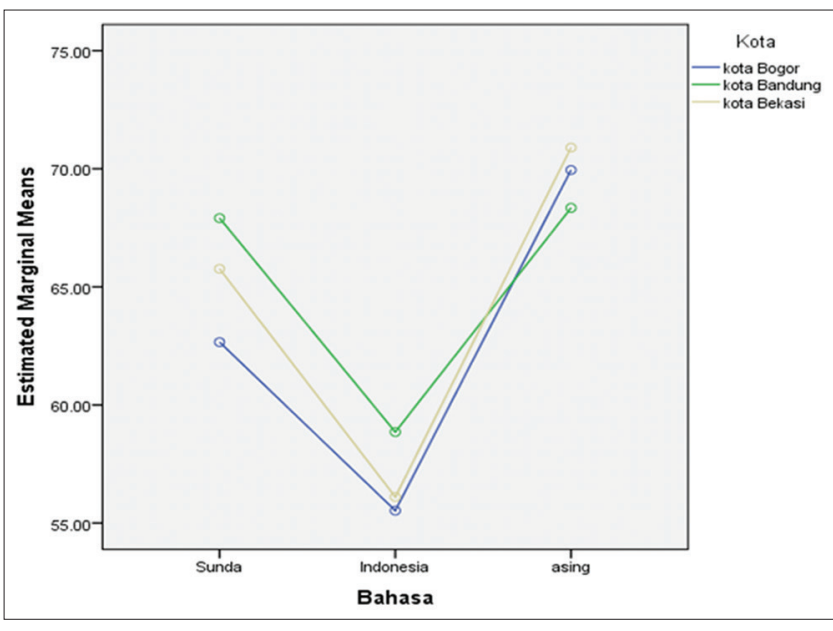

Diagram 4

(3) The language attitude of the Sundanese urban community in West Java to foreign languages is in a good category because the average reaches $69.85 \%$.

\section{Suggestions}

There are some findings in the study dealing with the language attitude of urban community in three big cities in West Java (Bandung, Bekasi, Bogor) that shows is not significant. Therefore, it will be very useful to carry out further research. Furthermore, Since this is the newest survey on language attitude on urban community in West Java, it will be very significant findings for those who are interested in multingual conditions in West Java, Indonesia.

\section{REFERENCES}

Cooper, R.L. (1978). "The Spread of Amharic in Ethiopia". Dalam J.A. Fishman (Ed.). Advances in the Study of So- cietal Multilingualism. The Hague: Mouton.

Fasold,, R. (1983). Variation in the Form and Use of Language: A Sociolinguistics. Reader: Washington, Georgetown University Press.

Fishman, J. (1972). The Sociology of Language. Rowley: Newbury House.

Gal, S. (1979). Language Shift: Social Determinants of Linguistic Change in Bilingual Austria. New York: Academic Press.

Gumpers, J. J. (1964). Linguistic and social interaction in two communities. American Anthropologist, 66 (6), 137--153.

Garvin. P.L. y M. Marthiot. (1968). The Urbanization of the $\mathrm{G}$ uarani language: a problem in language and culture. En A.C. Wallance (ed) Men and Cultures. Philadelphia: University of Pennsylvania Press, pp. 783-90.

Holmes, D. (1994.) An Introduction to Sociolinguistics. London: Longman.

Hudson, R.A. (1985). Sociolinguistics. Cambridge: University Press.

Ihemere, K. U. (2006). An integrated approach to the study of language attitudes and change in Nigeria: The case of the Ikwerre of Port Harcourt City. In Selected Proceedings of the $36^{\text {th }}$ Annual Conference on African Linguistics, ed. Olaoba F. Arasanyin.

Kridalaksana. H. (2001). Kamus Linguistik. Jakarta: PT. Gramedia Pustaka Utama.

Keller, X. (1968). Sociological Factors of Language Maintenance and Language Shift. A Methodological Approach Based on European and African. New York: J. Wiley

Mulyanah, A. (2017). The Study of Language Attitude of Sundanese Society in Cities in West Java toward Sundanese Language Based on Educational Background. Kolita 15: UNIKA Atma Jaya Jakarta 